\title{
Researching Latin America, part two: A survey of how the new generation is doing its research
}

Orchid Mazurkiewicz *

Tim Sturm **

Artículo recibido: 7 de noviembre de 2013.

Artículo aceptado:

7 de febrero de 2014.

\begin{abstract}
Students too often rely on Google for research, while demonstrating an alarming lack of awareness of other library resources. This is especially disconcerting to observe in graduate students who are expected to be experienced searchers and familiar with the resources in their fields. Following up on previous research done on US-based students, this paper seeks to assess the information-seeking behavior of Latin American graduate students. Student members of the Latin American Studies Association with mailing addresses in Latin America were contacted via mail and invited to respond to an online survey of their research

* University of California, Los Angeles, CA. USA. orchidm@ucla.edu

** American River College, Sacramento, CA, USA. sturmt@arc.losrios.edu ISSN: 0187-358X. pp. 163-192
\end{abstract}


strategies, including experience with bibliographic instruction and comfort level finding information on Latin America. Descriptive statistics were used to interpret the sample and Chi-squared tests to compare these results against those obtained in the previous survey. Respondents were found to feel comfortable and confident finding information using the preferred convenience of electronic media. They were also found to be unfamiliar with the research tools mentioned in the survey, and the majority had not received bibliographic instruction. There is clearly a need for faculty and librarians to work together to ensure these students are aware of the many available resources and to develop the information search skills they need to become effective researchers, scholars, or working professionals.

Keywords: Graduate Students; Information Seeking Behavior; Latin American Studies.

\section{Resumen}

La investigación sobre América Latina, segunda parte: un estudio acerca de cómo investiga la nueva generación

Orchid Mazurkiewicz y Tim Sturm

Los estudiantes dependen cada vez más de Google para realizar sus investigaciones y simultáneamente demuestran una alarmante falta de conocimientos acerca de los recursos de la biblioteca. Esto es especialmente desconcertante con los estudiantes de posgrado, de quienes se esperaría que estuvieran familiarizados con los recursos de investigación en su campo. En este artículo se trata de evaluar el comportamiento de búsqueda de información de los estudiantes latinoamericanistas de posgrado en la región, continuando las investigaciones anteriores realizadas con estudiantes latinoamericanistas estadounidenses. Los miembros estudiantiles de la Asociación de Estudios Latinoamericanos con direcciones en América Latina fueron contactados por correo y dirigidos a una encuesta en línea con preguntas sobre sus estrategias de investigación, sus experiencias con la instrucción bibliográfica y su nivel de comodidad hacia la búsqueda de información sobre América Latina. Se emplearon estadísticas 
descriptivas para describir la muestra y las pruebas del Chi-cuadrado fueron utilizadas para comparar estos resultados con los de la encuesta anterior. Los encuestados se sienten cómodos y seguros hacia la búsqueda de información, preferían la conveniencia de los medios electrónicos, no estaban familiarizados con los útiles mencionados en la encuesta y la mayoría no había recibido instrucción bibliográfica. Se necesita que los profesores y los bibliotecarios trabajen juntos para asegurar que estos estudiantes estén conscientes de los muchos recursos disponibles y desarrollen las habilidades de búsqueda de información que son necesarias como investigadores, académicos o profesionales.

Palabras clave: Estudiantes de Posgrado; Comportamiento sobre la Búsqueda de Información; Estudios Latinoamericanos.

\section{INTRODUCTION}

$\mathrm{T}$

his article reports on the second part of a two-part survey project investigating the information-seeking behavior and attitudes of Latin Americanist graduate students. The first part surveyed student members of the Latin American Studies Association (LASA) with mailing addresses in the United States and Puerto Rico (Mazurkiewicz \& Potts 2007). This second part surveys student members with mailing addresses in Latin America.

The authors of the first survey, both of whom had worked as Latin American studies librarians at Arizona State University, often found themselves frustrated with students' lack of awareness of the library's resources. Too often it seemed that if students could not find what they were looking for with a quick Google search they would assume that the information could not be found. This was particularly frustrating with graduate students since the nature of their studies requires a broad awareness of the literature of their field as well as in-depth research into their particular topic. While there is often an abundance of information resources available, both print and electronic, too much of it seems unknown or underutilized by students and researchers. The project was designed to help test the veracity of our assumptions and to develop a clearer picture of these students' information-seeking behavior, 
their awareness of research tools specific to Latin America, and their comfort level with research.

The hope is that the results of these surveys will be used by faculty, librarians, and the new generation of Latin Americanist researchers as starting points in assessing the ever-changing needs and research patterns of this sophisticated group of cross-cultural and cross-disciplinary scholars.

\section{Literature REVIEW}

Departing from where the original literature review concluded we find that students' information-seeking behavior continues as a popular area of research. While there have been no other studies that specifically target students in the field of Latin American studies, research into the information-seeking behavior of graduate students continues apace. While much of this research originates in the United States, there is a growing body of literature that addresses the information-seeking behavior and information needs of graduate students around the world.

Catalano's recent (2013) meta-analysis of forty-eight English-language studies of the information-seeking behavior of graduate students is a useful guide to trends in the literature. One recurrent finding in her analysis is that graduate students do not use advanced search techniques; although they become more adept at finding what they need, there is little evidence that they use the search strategies that librarians often promote. She cited both Perrett (in Australia) who found that $59 \%$ of students assessed needed search training and Hoffman (in Canada) who concluded that the most common difficulties for students were choosing keywords, refining searches, and dealing with information overload (266). In Hong Kong, Chu and Law studied postgraduates' research expertise and found that even at the $\mathrm{PhD}$ level students were not able to use advanced techniques effectively, although they did show improvement over time with some instruction (2007: 314). Earp's survey of graduate-level education students at Kent State University found that those surveyed "were not as advanced in their searching abilities as the faculty would have liked" (2008: 83). Korobili, Malliari, and Zapounidou's survey of graduate students at the Aristotle University of Thessaloniki found that students displayed low to medium level information-seeking skills and that Boolean operators, truncation, and proximity operators were seldom used (2011: 161-62). Malliari, Korobili, and Zapounidou, in a similar study at the University of Macedonia, found that most of the graduate students surveyed "used the simplest techniques” when seeking relevant information (2011: 85). 
Catalano cited multiple studies that found that graduate students overrate their ability to find information (2013: 266). Perrett found that 56 of the 107 graduate students surveyed overestimated their skill level (2004: 163). Malliari, Korobili, and Zapounidou found that more than half of the respondents considered themselves experts at searching the web and competent and proficient in searching databases and ejournals. (2011: 85) Korobili, Malliari, and Zapounidou found that students were more confident in their skills with search engines than databases or ejournals (2011: 157-158).

Assessing the benefits of bibliographic instruction, Rempel's longitudinal study concluded that Oregon State University graduate students who attended a library literature review workshop demonstrated an increased sophistication in their searching (2010: 538). Malliari, Korobili, and Zapounidou also found a relationship between advanced search techniques and attending a library instruction workshop, although use of these techniques remained low (2011: 8385). Damasio's study of graduate-level pharmacy students at the Universidade Estadual de Maringá found that they benefited from librarian intermediation in their effective use of online resources (2010: 379). As mentioned above, $\mathrm{PhD}$ students demonstrated a better understanding of search techniques after training in Chu and Law's study (2007: 314). Formal information literacy training also significantly improved undergraduate and graduate finance students' information-seeking behavior at Rutgers University (Long \& Shrikhande, 2005).

Librarians recognize that many students begin their research on the Internet. While there might be some expectation that this would be less prevalent with graduate students with their more complex information needs the research suggests otherwise. Catalano concluded in her meta-analysis that "both masters and doctoral students are inclined to begin their research on the Internet" even though the unreliability of many sources on the Internet is recognized (2013: 260). Vezzosi's survey of doctoral students in biology at the University of Parma found that nearly all reported starting their research on the Internet, although they seemed aware of its shortcomings (2009: 69). Earp reported in her survey of graduate-level education students that the majority reported beginning their research on the Internet (2008: 82). Malliari, Korobili, and Zapounidou also found that the most common method used to find information was searching the web (2011: 82). Garcia and Silva, in their study from the Universidade Estadual Paulista, noted the appeal of the simple interfaces of Internet search tools in comparison to the various barriers to maximizing the use of a library's resources such as database selection, advanced search techniques, and controlled vocabularies (2005).

Recent literature also describes the predominance of ejournals and the importance of electronic availability in a student's choice of information. A 
comprehensive study of Generation Y doctoral students in the UK found that ejournals dominated the types of sources normally used to find information (Researchers of tomorrow, 2012: 19). Furthermore, if students could not find the fulltext, almost half said they would make do with the abstract (Researchers of tomorrow, 2012: 19). Catalano also noted rising ejournal use as a trend (2013: 261). Earp found that "electronic availability" was the most important factor in students choosing a journal and noted that many students would not use an article if unavailable in fulltext (2008: 81, 84). Kayongo and Helm's survey of library use among graduate students at the University of Notre Dame found that $62.8 \%$ of respondents preferred the electronic version of a book or article (2010: 343). Vezzosi reported that all students had a preference for electronic resources over print (2009: 70). Ge found that students used free ejournals on the web because they did not fully understand what was available through library subscription databases (2010: 441-442).

Faculty expectations and the importance of their role in the training of graduate students is also a recurring topic in the literature. Fleming-May and Yuro study from the University of Alabama noted that faculty expect students to arrive in their graduate programs as competent researchers and accordingly do not provide research instruction from faculty (2009: 210). They also suggested that a faculty member's endorsement of a librarian's ability may be one of the most important factors in shaping how a student views the library (2009: 215). Catalano described research showing that faculty themselves are not always expert searchers and are sometimes unaware of the training available at their institutions (2013: 264). She concludes that it is faculty who should receive bibliographic instruction, particularly graduate student advisors (2013: 268). Monroe-Gulick and Petr concluded that the "important role of teaching faculty in delivering information literacy guidance emerged as a dominant finding" in their research on incoming social science graduate students at the University of Kansas (2012:327).

Catalano found that students prefer to ask faculty for research guidance and rarely ask librarians (2013: 263). Fleming-May and Yuro reported that students sought "negligible assistance from librarians," although they also noted students' reluctance to ask for help at all, even from faculty (2009: 211). Earp found that $84.9 \%$ of her respondents rarely or never sought help from a librarian (2008: 83). Similarly, $86 \%$ of the graduate students in Santos's study reported not making use of the bibliographic instruction programs offered at their Brazilian universities (2008: 76). The UK study Researchers of Tomorrow found that over $50 \%$ of respondents indicated that they had never sought advice from subject-specialist librarians and only about 5\% used their services regularly (2012: 58). Similarly, only $50 \%$ of 
respondents in Garcia and Silva's (2005) study turned to a librarian for research assistance. Korobili, Malliari, and Zapounidou (2011), Malliari, Korobili, and Zapounidou (2011), and Kayongo and Helm (2010) all reported on the under-use of librarians as an information-seeking resource. Monroe-Gulick and Petr noted that "students seemed not to consider librarian assistance during the research process" (2012: 328). Rempel found that students mostly rely on self-taught research skills and thought that the complexity of their research was too advanced for librarians to understand (2010:541). Du and Evans found that $40 \%$ of participants doubted the effectiveness of assistance from librarians (2011: 111). Although Vezzosi found that students valued library services, research assistance from reference librarians was not mentioned as being one of these services (2009: 72-73).

Considering the high use of the Internet and electronic sources for research, it is not surprising that similar trends are found in studies from various regions around the globe. Nevertheless, only minimal research has been done to assess the generalizability of results on information-seeking behavior between countries. Romanos de Tiratel (2000) considered the question of whether UK- and US-based research on libraries and librarianship could be applied to countries without the same level of access to library systems and services. Comparing the results of her study of Argentine scholars to the literature from abroad, she concluded that researchers share common traits in their information needs and the same manner of accessing resources "despite the quality and quantity of resources and dissimilar working environments" (353). Cortés (2006) noted that while there are many studies on US students and their information needs and library use, there are far fewer on Mexican students and even less that make comparisons between the two groups (11). In their study of the applicability of the ACRL information literacy competency standards for Mexican universities, they found that Mexican and US students shared as many similarities as differences, but that Mexican students had a longer road to travel to meet these standards. In addition to more limited access to library resources and information technology and deficiencies in teacher training that helped to explain these differences, the authors also noted ethnopsychological differences in students' research behavior. Nevertheless, Cortés described a Mexican student population that includes many who have studied in the US and brought back research practices and expectations from their experiences north of the border (2123). Francis also mentioned training abroad as a possible explanation for the similarities she found in the information-seeking behavior of social science faculty at the University of the West Indies to those described in studies of scholars from more developed countries (2005: 71). Al-Suqri (2011) studied 
the scholars at the Sultan Qaboos University in Oman to determine whether a model of information-seeking behavior based on studies in Western countries could be applied to other regions of the world. He found that, in general, this could be done, but that the model might not be sufficient without the incorporation of additional contextual factors such as the limited availability of resources, poor Internet connectivity, and language constraints.

\section{Method}

Based on the original project's literature review and personal experience, the initial assumptions concerning the research and information-seeking behavior of Latin Americanist graduate students were: 1) students would not have a high level of awareness of the core tools in the field, 2) students who had received bibliographic instruction would be more likely to be familiar with the field's core tools, 3) medium or format would be an important determinant in the choice of research tools, and 4) the Internet would be a prominent tool for research. A three-part survey (owing much to Marcum and George's 2003 study) was designed to test these assumptions, as well as to gather some additional data on information-seeking behavior, and on students' perceptions of their ability to successfully carry out Latin American-related research. The first section ("How you do your research") included general questions related to the use of print versus electronic and library versus Internet resources when conducting Latin America-related research. A combination of Likert scale and multiple-choice questions allowed us to approximate and compare students' comfort levels with locating and using different kinds of research materials and search strategies.

The second section ("The tools you use for Latin America-related research") included questions on preferred tools for research and questions related to awareness and use of four Latin America-specific research tools. The tools were chosen based on the original authors' professional experience and training as US-based librarians, and on a review of a variety of librarians' online research guides. The four tools were:

1) The Handbook of Latin American Studies (HLAS) (http://lcweb2. loc.gov/hlas/) is a selective, annotated bibliography produced by the Hispanic Division of the US Library of Congress. Published since 1936, it covers both the social sciences and humanities and is available in both a print volume and in a free online database. One of the oldest and most esteemed resources of its kind, HLAS is the "... 
principal ongoing bibliography of publications on Latin America." (Covington, 1992: 3, 72; see also McNeil \& Valk, 1990) It does not provide the fulltext of cited sources.

2) The Hispanic American Periodicals Index (HAPI) (http://hapi.ucla. edu), previously available in print and now exclusively online, includes citations to more than six hundred periodicals from the field of Latin American studies dating back to 1970. It is the only one of the four tools that requires a paid subscription. Historically, it has had a limited subscriber base in Latin America but this has grown in recent years as HAPI developed a tiered pricing structure for Latin American institutions and eventually became free to institutions in the region as of 2009. It is considered a "principal index to journals on Latin American themes" (Covington, 1992: 53, 71; see also McNeil \& Valk, 1990: 216). While it does not include fulltext, it does include links to fulltext when available online-including links to widely-used subscription services such as JSTOR as well as to the freely available content on individual journal websites and Latin American aggregators such as Redalyc and SciELO. Over $75 \%$ of the journals published in Latin America that are currently indexed in HAPI are freely available online.

3) The Latin American Periodicals Table of Contents (LAPTOC) (http://laptoc.library.vanderbilt.edu) was a product of the Latin Americanist Research Resources Project (LARRP), which itself is a project of the US-based Center for Research Libraries. LAPTOC was a searchable database of the tables of contents of more than eight hundred scholarly periodicals published in Latin America. Founded in 1997, it was created to fill the gaps in access to the region's vast periodical literature left by HLAS and HAPI and was freely available online. Funding and content was provided by the LARRP member institutions. Unfortunately, it is now defunct and no new content is being added but it is still searchable via a database hosted by Vanderbilt University. While LAPTOC was a relatively young resource compared to the others, the authors were curious about its use as it was freely available and many US academic libraries had invested in its production.

4) The Latin American Network Information Center (LANIC) (http:// lanic.utexas.edu) is one of the largest organized gateways to Latin American content on the Internet. It is affiliated with the University of Texas at Austin and includes editorially reviewed directories to relevant Internet sources, as well as hosting a variety of fulltext projects, such as a database of presidential messages. It is generally 
recognized among US-based Latin Americanist librarians as an important starting point for organized access to Latin America-related websites, although funding cuts in the last few years have limited its maintenance.

The final section of the survey ("Information about you") asked respondents about the degree they were working on, year of study, majors, languages used in research, the country in which they were studying, and whether they had received bibliographic instruction from librarians and/or class instructors.

The Latin American Studies Association student members were seen as an ideal target population as they identify themselves, at least to the extent of becoming LASA members, as Latin Americanists. They are also unlikely to "have built up the same information reserves as more established academics: rich personal collections of publications and a network of personal contact with expert colleagues, which can short cut the need for extensive information seeking" (Barry, 1997: 229). These students are also likely to be the next generation of instructors in the field of Latin American studies, passing along their own knowledge of research tools and strategies to the following generation of students.

LASA sells lists of their members' mailing addresses but not of their email addresses. Cost and logistical constraints limited the first stage of the survey to LASA student members with postal addresses in the United States and Puerto Rico. In part one of the project, the survey was mailed to 667 Latin American Studies Association student members with mailing addresses in the United States and Puerto Rico and 211 surveys (31.6\%) were returned. Nevertheless, the researchers believed that the results would be incomplete without data from students based in the region itself. Disparities in access to resources between the US and Latin America impact the research process and the nature of scholarly communication. Scholars in Latin America (and the global South in general) often work in libraries with limited funds for the acquisition of print and digital materials, the preservation of archival and special collections, and the library personnel essential for accessing these resources. For example, in an issue of the Latin American Studies Association's newsletter, Tinker-Salas (2009) described a panel on research practices at a LASA meeting in Rio de Janeiro. The panel quickly shifted from the expected focus on good research practices to a discussion dominated by the Latin American participants' frustrations with lack of access to journals. "The economic requirements of the [Northern] publishing world create barriers that limit the full democratization of knowledge and aggravate 
structural differences between the North and the South. Invariably, many resource-strapped universities in Latin America are unable to purchase these services; thus colleagues in the region confront a structural disadvantage in gaining access to these materials" (Tinker- Salas, 2009: 6). Ground-breaking Open Access initiatives in Latin America have been one response to these structural differences (see Poynder, 2013; http://www.scielo.org; http:// www.redalyc.org; http://www.clacso.org.ar). The second stage of this project was seen as an essential step in creating a more inclusive understanding of the LASA student scholars' information seeking behavior.

By the time funding was secured for the second stage, we were able to take advantage of inexpensive online survey tools. Spanish and Portuguese versions of the original request to participate in the survey were mailed to the 201 LASA student members with addresses in Latin America (Portuguese for Brazilian addresses and Spanish for the remainder). The letter directed recipients to an online version-either Spanish or Portuguese-of the survey. In early 2010, fifty-six online surveys $(27.8 \%$ ) were submitted.

\section{SuRvey RESUlts}

\section{The respondents}

Two of the respondents had completed their doctorate, forty-three were working toward a doctorate, four were in master's programs, and one was an undergraduate (not all 56 respondents answered this question). This closely mirrors the proportions among the US-based respondents in the first survey (hereafter referred to as Group One).

The LA-based survey respondents were asked which countries they study in (hereafter referred to as Group Two). The largest numbers of respondents studied in Brazil (eighteen) and Argentina (twelve), followed by the United States (seven) and Mexico (six). Three respondents reported studying in France and one respondent studied in each of Canada, Cuba, Ecuador, Guatemala, Peru, and Spain. Of those listed above, one respondent reported studying in both Argentina and France, and another in both Peru and France.

Similar to Group One, anthropology, history, political science, sociology, and literature were the top areas of study. Art/art history, economics, education, geography, languages/linguistics, music, and the sciences were each selected by two to three respondents. Just under $30 \%$ of respondents selected multiple disciplines. This, along with the write-in subjects of social memory, 
urbanism, and agro-ecology, might suggest the increasingly interdisciplinary nature of scholarship on the region, a trend also suggested by Group One.

\section{Languages of research}

The survey asked Group Two respondents to write in, from most-used to least-used, the top three languages they use to conduct their Latin America-related research. As expected, considering the population surveyed, $73 \%$ of respondents listed Spanish or Portuguese as their top language, and $42 \%$ listed one of these as their second language of research. English was listed as the top language for $16 \%$ of respondents. Three of these nine respondents reported studying in the United States. English, Portuguese, or Spanish were listed by $48 \%$ of the respondents as their third language of research. French was the only other language listed, with two respondents citing it as their second language of research and nine as their third. Interestingly, when all three choices are considered, English was the most commonly listed language. Only three of the forty-nine respondents who answered the question did not include English as one of their languages of research. Nine of the respondents did not list Spanish among their top three languages and twenty-seven did not list Portuguese. Perhaps this reflects the dominance of English in the "geopolitics of academic writing," as Canagarajah (2002) calls it, and the need for English proficiency as "a career-defining issue for many scientists and researchers around the world" (Cronin, 2009: 433).

\section{Research and information-seeking behaviour}

As we had assumed, the majority of Group Two respondents reported that the medium of information was an important factor in deciding to use that information. Over $60 \%$ of respondents reported that the medium was either extremely important or very important in their decision. This is a change from the results of Group One where $60 \%$ reported that the medium of the information was either somewhat or not at all important. This shift might reflect the passing of a few years between surveys-as the availability of full text grows so too does the preference for it. As described in the literature review, current research overwhelmingly reports that students prefer electronic media to print.

Nevertheless, the growing availability of electronic resources has not yet eliminated the use of print resources. Exactly as in Group One, $73 \%$ of Group Two respondents reported that they use print resources when doing their Latin America-related research either all of the time or most of the time. Up from $62 \%$ of the Group One respondents, $79 \%$ reported that the same 
was true regarding electronic resources. Despite a preference for digital materials, online sources do not yet meet all these students' research needs.

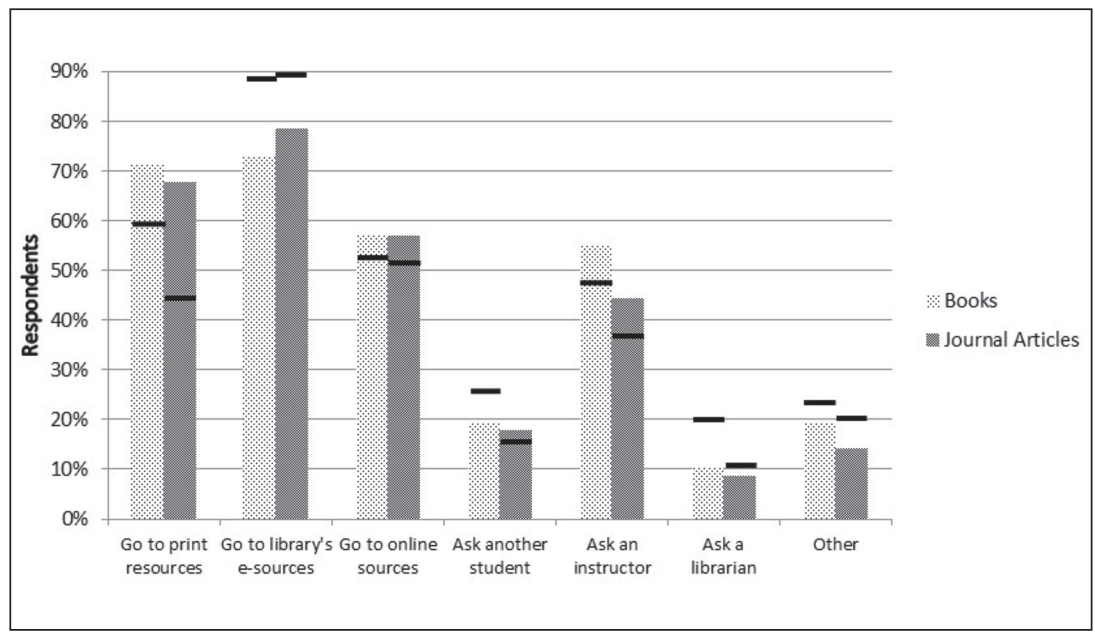

Figure 1. How students find books and journal articles with lines showing responses from Group One.

Generally, both groups of students report similar strategies for finding books and journal articles for their Latin America-related research (see Figure 1; see also Group One responses in the Appendix, Figure 5). Nevertheless, there is a highly significant statistical difference in the use of print and library e-resources to find books and journal articles between the two groups $\left(\chi^{2}=6.1, \mathrm{df}=1, .02>\mathrm{p}>.01\right)$. This difference seems understandable when considering that many Latin American academic institutions do not have the same abundance of electronic resources commonly found in US institutionswhere the greater challenges are information overload and choosing among the many databases available via institutional subscription (Monroe-Gulick \& Petr, 2012: 329). For example, the University of California, Los Angeles libraries provide access to over one thousand databases. Mexico's largest public university, the Universidad Nacional Autónoma de México, has just over two hundred according to their online catalog of databases. In 2006 Cortés reported that US university library expenditures on electronic resources had already equaled that spent on print materials-a trend that has continuedand that Mexican academic libraries had only begun their efforts to build the digital library (61; The 2012 State of America's Libraries: 29). Nevertheless, the library's electronic resources are still the most popular source for finding books and journal articles. Consistent with the literature, these graduate students look to their instructors and, less so, their peers for assistance in their 
research. Also consistent with the literature is the dishearteningly low use of librarian expertise as part of a search strategy.

Respondents were asked their level of agreement with the statement, "Browsing the stacks or journal shelves in a library is an important way for me to get information when doing Latin America-related research." This traditional method of finding resources remains popular- $66.6 \%$ of Group Two students agreed or strongly agreed with this statement. As well, $87.5 \%$ of respondents either agreed or strongly agreed that "Using citations from bibliographies is an important way for me to get information when doing research on Latin America-related topics." This supports the findings in Vezzosi's survey where students stressed the importance of citation chaining as a method of finding information (2009: 71).

Despite the continued popularity of these search strategies, the library is losing its traditional role as the place where research is conducted. Only $32 \%$ of Group Two respondents agreed or strongly agreed with the statement "My institution's library (physical and/or virtual) is where I conduct most of my research on Latin America-related topics" and $52 \%$ disagreed or strongly disagreed. Compare this with the results in Group One, where $67 \%$ of respondents either agreed or strongly agreed with this statement. This might reflect the passing of time between the surveys and the growing availability of materials outside of the traditional repositories of scholarly information. It might also reflect the growing invisibility of the library's role in providing subscriptions to Internet-based information. Providing seamless, easy access to subscription-based electronic resources has been a goal for academic libraries for many years, as seen in the use of IP authentication, proxy servers, and openurl linking as well as the growth of federated search tools and now discovery services. This can make it difficult for students to recognize that the information they are accessing has been provided by the university library's subscription. Nevertheless, students in Latin America may be driven to the open Internet out of necessity due to the limitations of library budgets, as mentioned above. The enthusiastic embrace of Open Access in scholarly communication and the extraordinary achievements of Latin American Open Access initiatives provide free alternatives for students of Latin American studies-both North and South.

\section{Use of research tools}

One might expect that graduate students would be among the heaviest users of the four tools mentioned in the survey. They have sophisticated research needs, often exploring their topics both in depth and breadth. However, 
consistent with the pre-survey assumptions, results for use levels were low. When asked whether they had ever used these research tools, $19.6 \%$ of Group Two chose yes for LANIC, $12.5 \%$ for HLAS, $10.7 \%$ for HAPI, and only $5.3 \%$ for LAPTOC. The results from Group One of the study were also disappointingly low but were substantially higher than these, with the exception of LAPTOC ( $63.3 \%$ for LANIC, $43.9 \%$ for HLAS, $46.4 \%$ for HAPI, and just $2.8 \%$ for LAPTOC). Despite these modest sample sizes, we can be 98 to $99 \%$ confident that use of the four databases varies between the two study groups $\left(\chi^{2}=11, \mathrm{df}=3, .02>\mathrm{p}>.01\right)$. When asked the reason for not using each tool, lack of awareness of the existence of the tools was the most cited reason, as seen in Figure 2 (see also Appendix, Figure 6). Clearly, outreach to promote the greater use of these freely available tools remains to be done-both to Latin American students and the faculty who are so critical in shaping students' perceptions of the importance of a resource.

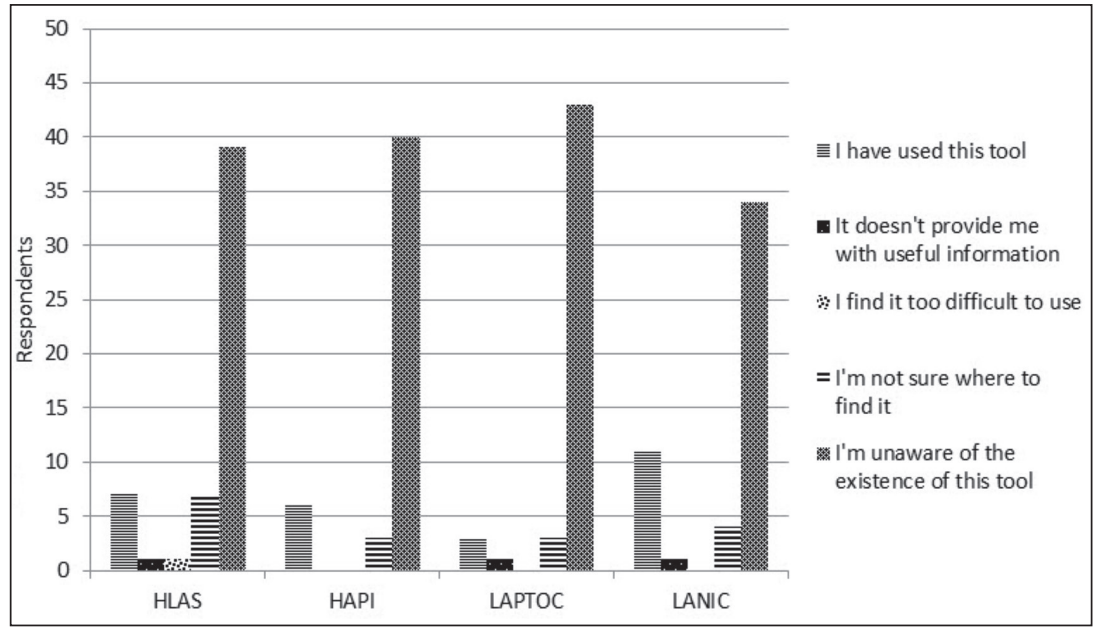

Figure 2. Reasons for non-use of tools.

Group Two respondents were asked what they considered the three most useful tools when doing Latin America-related research. Since this was an open-ended question, a wide variety of tools were listed and, not surprisingly, electronic resources predominated (see Table 1). A number of important Open Access regional initiatives were among the results: SciELO, CLACSO, and Redalyc were each cited by multiple respondents. Surprisingly, in a time when "google" has become a verb, neither Google nor Google Scholar were as popular as might be expected. One interesting contrast is the almost complete absence of discipline-specific tools (such as EconLit, PsycINFO, Popline, 
Sociological Abstracts), which were heavily represented in Group One's responses (see Appendix, Table 3). We also see the presence of vendors (EBSCO, Sage, Springer, and Taylor) who package collections of research tools and make them available to libraries via subscription. They clearly do a good job of branding their products, although perhaps at the expense of researchers' awareness of what is actually being searched within that package.

Table 1. Most useful tools for Latin America-related research in order of number of respondents.

\begin{tabular}{|l|c|l|c|}
\hline JSTOR & 14 & Cairn & 1 \\
\hline SciELO & 7 & Casa de las Américas & 1 \\
\hline CLACSO & 4 & ebrary & 1 \\
\hline Libraries & 4 & HAPI & 1 \\
\hline Google & 3 & Jornal Independente & 1 \\
\hline Google Scholar & 3 & LATINDEX & 1 \\
\hline Redalyc & 3 & Notre Dame University website & 1 \\
\hline Amazon & 2 & Print resources & 1 \\
\hline Databases & 2 & Sage & 1 \\
\hline EBSCO & 2 & Scopus & 1 \\
\hline Journals (specialized) & 2 & Springer & 1 \\
\hline Online sources & 2 & Taylor & 1 \\
\hline Portal CAPES & 2 & Web of Science & 1 \\
\hline Anthroplus & 1 & Wikipedia & 1 \\
\hline Biblioteca Digital UNAM & 1 & & \\
\hline
\end{tabular}

The most obvious similarity between the two groups of respondents is the selection of JSTOR as the most popular research tool. It received sixty-one votes in Group One ( $31 \%$ of respondents) compared to fourteen votes $(25 \%$ of respondents) in Group Two. They both significantly outdistanced the next runner-up in popularity: OCLC WorldCat/FirstSearch with forty-two votes in Group One, and SciELO with seven votes in Group Two. JSTOR (http://www.jstor.org) is an online full text archive of over two thousand scholarly journals covering both the arts and social sciences, including a Latin American Studies collection of sixty-one titles. It is an incredible resource-it is well-designed and easy to use, access to its contents is typically quick and reliable, and the full text of journals starts with the first issue of a journal onward, although often with a moving wall limiting access to the most recent issues. It is widely held in academic libraries. However, within the Latin American Studies collection, approximately $20 \%$ of the titles are published in Latin America and the Caribbean, the remainder primarily published in the United States and Western Europe. While there is Latin American content in JSTOR's other subject journals (anthropology, 
psychology, history, etc.), it is surprising that such a relatively small universe of mainly US publications would be so popular among both groups of graduate students. Students may see it as a good starting place for their researchand few of us can resist the appeal of instant full text gratification. However, as researchers become more accustomed to the availability of full text online, there is a growing concern that a "full-text-fixated generation of researchers...will readily pass up valuable information... simply because full-text content is not instantaneously available" (Bell, 2003: 44).

\section{Bibliographic instruction}

The Group Two survey respondents were also asked about their experiences with bibliographic instruction on how to conduct Latin America-related research: $16 \%$ responded that they had received research instruction from a course or instructor, only $7 \%$ reported that they had received research instruction from a librarian-compared to $44.5 \%$ and $34.5 \%$ respectively for Group One-and no-one reported receiving instruction from both. (The concept of bibliographic instruction was used loosely in the survey, and the authors acknowledge that there are different approaches to promoting the use of library resources, ranging from one-shot librarian-taught sessions to credit-bearing research methods courses.) This is consistent with research suggesting a gap between faculty assumptions about the research skills of graduate students, and what the students actually know. Faculty assume that graduate students are skilled in using the library and so perhaps do not include bibliographic instruction (provided either by themselves or a librarian) in their graduate courses. The survey shows that respondents have developed strategies for carrying out their research, despite a lack of formal instruction-although the question remains as to whether these are the most efficient or effective strategies. As the literature suggests, there is room for improvement in graduate students' search skills and instruction from librarians can make a difference. Nevertheless, as Uribe saw in Venezuela, not all academic libraries are offering bibliographic instruction, or at least aren't actively promoting it as a library service, despite recognizing its significance in their educational mission (2012: 82; see also Pinheiro et al., 2008). This is not surprising considering that the same resource limitations that restrict libraries' access to print and electronic acquisitions can also restrict the staffing levels necessary to support outreach and instruction programs.

In the results from Group One, the pre-survey assumption that students who had received bibliographic instruction would be more likely to be familiar with the four tools got only moderate support from the survey results (see Appendix, Figure 7). There was no statistical correlation between those who had 
received one type of instruction (instructor or librarian) and those who had received none and their use of HLAS, HAPI, or LANIC. However, there was a positive correlation for all three when the student had received instruction from both an instructor and a librarian. Unfortunately, chi-square tests revealed that responses from the second survey were too few to run viable linear regression models. Of the seven Group Two respondents who had used HLAS, five had no instruction and two had instruction from a librarian; for the six who had used HAPI, one had no instruction, three received instruction from an instructor, and two from a librarian; two of the three LAPTOC users had received instruction from a librarian and the third did not answer this question; and seven of the eleven LANIC users received no instruction, one received instruction from an instructor, and the remaining two received instruction from a librarian (see Table 2). Nevertheless, the importance of librarian-faculty collaboration is increasingly seen as critical to the success of developing students' information literacy skills, in both the North and South (Romanos de Tiratel, 2002: 305; Monroe-Gulick, 2012; Lau, 2001).

Table 2. Bibliographic instruction and use of the four tools.

\begin{tabular}{|l|c|c|c|c|}
\cline { 2 - 5 } \multicolumn{1}{c|}{} & HLAS & HAPI & LAPTOC & LANIC \\
\hline No instruction & 5 & 1 & 0 & 7 \\
\hline From Instructor & 0 & 3 & 0 & 1 \\
\hline From librarian & 2 & 2 & 2 & 2 \\
\hline Total & 7 & 6 & $2^{*}$ & $10^{*}$ \\
\hline
\end{tabular}

\section{Assessing comfort/confidence levels with library resources}

Several Likert scale questions on the survey prompted students to assess their own comfort levels with identifying and using library resources. Students were asked how much they agreed with the statements "I am comfortable locating and using print resources when doing Latin America-related research" and "I am comfortable locating and using information electronically when doing Latin America-related research." Figure 3 shows that $75 \%$ and $89.2 \%$ respectively either agreed or strongly agreed with these statements (see also Appendix, Figure 8). Chi-square tests reveal that the differences between Group One and Two in this regard are not statistically significant. 


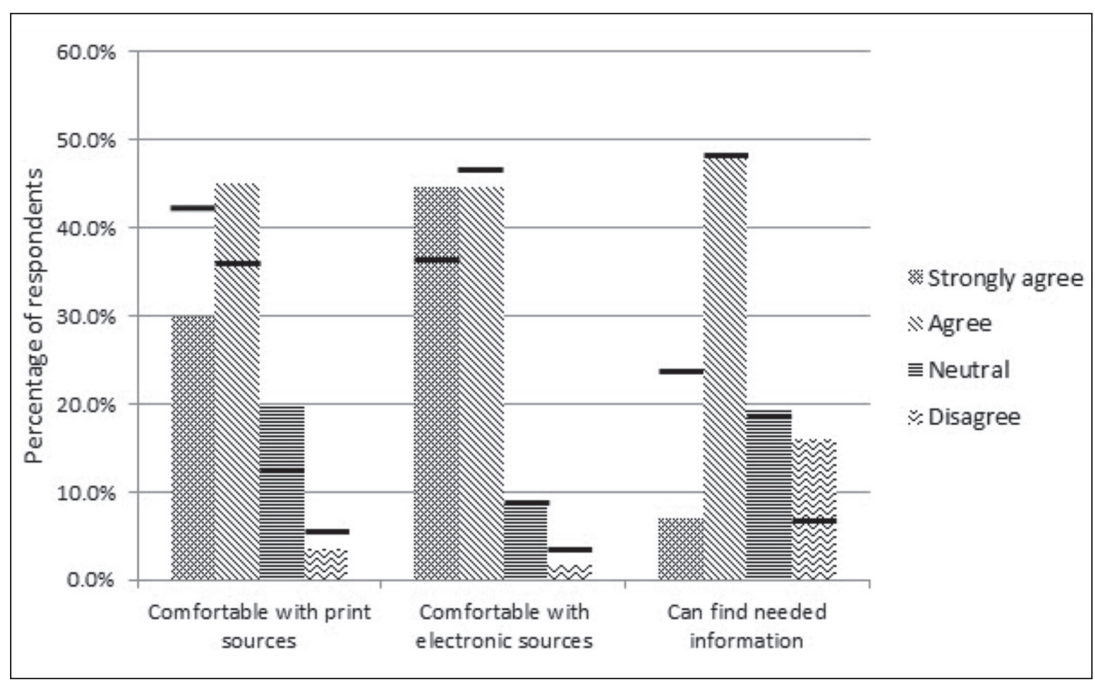

Figure 3. Self-assessed comfort levels with lines showing responses from Group One.

There was a more tempered agreement among Group Two respondents with the general statement "I can find the information I need on Latin America-related topics." Figure 3 shows a similar level of agreement (48\%) with this statement as with the previous two statements, but a low level of strong agreement (just $7 \%$ ). This also had the highest level of disagreement among the three questions with $16 \%$ of respondents disagreeing. No respondents strongly disagreed with any of the three statements. Group One respondents also expressed lower levels of strong agreement with this statement than with the previous two statements, but at $25 \%$ it is still higher than we see here. Indeed, we see highly significant differences between the two groups' levels of agreement and strong agreement with this statement $\left(\chi^{2}=5.2 \mathrm{df}\right.$ $=1, .05>\mathrm{p}>.02$, Yates $=.5)$. The level of disagreement among Group One was slightly less than half that $(7.5 \%)$ of the Group Two respondents. With almost $36 \%$ of these LA-based students responding neutrally or disagreeing with this statement it seems there are still challenges to face in assisting them in meeting their research needs.

In Group One, respondents who had received research instruction from an instructor or from both an instructor and a librarian (although not solely from a librarian) had statistically significant higher levels of agreement with this statement than did other respondents (see Appendix, Figure 9). A Pearson's $r$ correlation was run for the Group Two respondents but only a very weak positive correlation was found between levels of bibliographic instruction and the ability to find the information needed on Latin American topics 
$(r=0.110296571)$. Figure 4 shows the percentage of Group Two respondents by type of instruction for each level of agreement with the general statement. Lack of instruction does not seem to be hampering respondents' sense of efficacy in their research as two thirds of the thirty-seven respondents who received no instruction report either agreement or strong agreement with the statement.

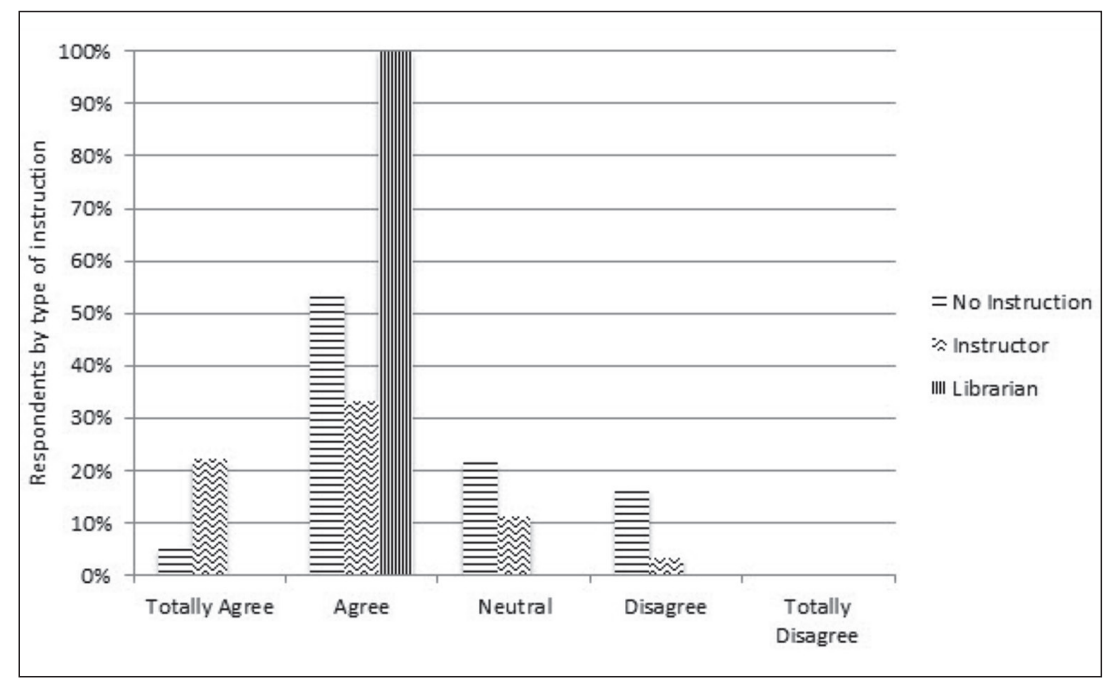

Figure 4. Agreement with "I can find the information I need on Latin America-related topics" and bibliographic instruction.

In Group One, there was evidence of higher levels of agreement and strong agreement with the statement "I can find the information I need on Latin America-related topics" among users of two or more of the tools. Nevertheless, $62.5 \%$ of those who either agreed or strongly agreed had not used any of the four tools. Unfortunately, the sample size in Group Two is too small to show a clear relationship between dependent and independent variables when assessing levels of agreement with the statement and use of the tools but, similar to Group One, $65.5 \%$ of respondents who had used none of the tools either agreed or strongly agreed with the statement.

\section{Conclusions}

Together, the two sets of survey results provide an overview of the information-seeking behavior and attitudes of the LASA student members-almost all 
$\mathrm{PhD}$ students, many of whom are likely to become part of the next generation of researchers and professors studying Latin America. Comparing the results provides a glimpse into the similarities and differences between the two groups of students-those based in the US and those based in Latin America. The results of our survey do not stray far from what is found in the current research on the information-seeking behavior of graduate students. Both groups of survey respondents generally feel comfortable and confident finding information, both in print and electronic form; they prefer the convenience of electronic media; and the majority are not receiving bibliographic instruction.

Compared to their peers in Group One, the LA-based respondents of Group Two have a stronger preference for electronic resources and yet are even less likely than the former to be familiar with the four online tools for which use was measured. While sharing a fondness for JSTOR and electronic resources, the two groups of respondents show differences in their choice of the most useful tools for research. While librarians might be disappointed in the numbers of students in the Group One who had received some kind of bibliographic instruction for Latin America-related research, even fewer of the Group Two respondents received this training. Group Two respondents were less confident that they could find the information they needed than Group One. With a quarter responding neutrally or disagreeing, there is clearly a need for faculty and librarians to work together to ensure these students are aware of the many available resources (print and electronic) and to develop the information-seeking skills they will need as researchers, scholars, or working professionals.

Nevertheless, some structural barriers in information access will not be overcome by greater faculty-librarian collaboration and outreach to students. These barriers must be considered as we continue to investigate the information-seeking behavior of graduate students and to assess the generalizability of this research beyond national borders-even beyond national borders within the region. Future research might consider the impact of disparities among Latin America-based students as well. While the Group Two respondents all had addresses in Latin America and the Caribbean, two thirds of those were in Brazil, Mexico, and Argentina-the three wealthiest nations in the region. Latin America is often studied as a whole, but historical and socio-economic differences hinder easy generalizations among the region's countries. The second survey results might have been significantly different had the respondents included more students from the poorer Andean nations or Central America. Future research might consider the possible impact of Open Access resources and the shrinking digital divide on the research behavior of Latin Americanist students (North and South). 


\section{Acknowledgements}

The authors wish to thank the Librarians' Association of the University of California for their generous financial support of this project. Thanks also to Paloma Celis Cabajal, Alison Hicks, and Andrea Saladino for their feedback; and a special thanks to Bruce Bachand for his invaluable assistance with our statistical tests. We are also grateful to all LASA student members who took part in this survey.

\section{REFERENCE LIST}

Al-Muomen, N.; Morris, A. \& Maynard, S. (2012), "Modelling information-seeking behaviour of graduate students at Kuwait University”, Journal of Documentation, 68 (4), 430-459. DOI:10.1108/ 00220411211239057

Al-Suqri, M. N. (2011), "Information-seeking behavior of social science scholars in developing countries: A proposed model", International Information E Library Review, 43 (1), 1-14. DOI:10.1016/j. iilr.2011.01.001

Barragán, C. \& Encuentro, de D. de H. I. (2006), Desarrollando babilidades de información como parte de un aprendizaje basado en la experiencia para los usuarios de la Biblioteca del Tecnológico de Monterrey: campus Monterrey, Ciudad Juárez, Chihuahua: Universidad Autónoma de Ciudad Juárez.

Barry, C. A. (1997), "Information skills for an electronic world: training doctoral research students", Journal of Information Science, 23, 225-38.

Bell, S. J. (2003), "Is more always better?", American Libraries, January, 34 (1), 44.

Canagarajah, A. S. (2002), A Geopolitics of Academic Writing, Pittsburgh, PA: University of Pittsburgh Press.

Calva González, J. J. (2009), "El comportamiento en la búsqueda de información de los investigadores del área de Humanidades y Ciencias Sociales", Investigación Bibliotecológica, 13 (27), 12-40. Retrieved from http://revistas.unam.mx/index.php/ibi/article/view/3917

Catalano, A. (2013), "Patterns of graduate students' information seeking behavior: a meta-synthesis of the literature", Journal of Documentation, 69 (2), 243-274. DOI:10.1108/00220411311300066

Chu, S. K. \& Law, N. (2007), "Development of information search expertise: postgraduates' knowledge of searching skills", portal: Libraries and the Academy, 7, 295-316. 
Cortés, J. (2006), “Semejanzas y diferencias entre estudiantes norteamericanos y mexicanos como usuarios de la información: una aproximación a su estudio", in J. Tarango, G. Ascencio \& P. Murguía (eds.), Información sin fronteras: Compartición de experiencias sobre bibliotecas y centros de información, Chihuahua, México: Universidad Autónoma de Chihuahua, Facultad de Filosofía y Letras, 9-25. Retrieved from http://eprints.rclis.org

Covington, P. H. (ed.) (1992), Latin America and the Caribbean: A critical guide to research sources, Westport, CT: Greenwood Press.

Cronin, B. (2009), "Vernacular and vehicular language", Journal of the American Society for Information Science E Technology, 60, 433.

Cuenca, A. M. B., Universidad de S. P. (Brasil) \& Seminario N. de B. U. (2000), Uso da internet por usuários de bibliotecas acadêmicas, Santa Catarina, Brasil: Universidad de São Paulo.

Cunningham, N. (2000), "Collaborating with faculty: do they understand us? Do we understand them? Do we share the same objectives?”, in J. Lau \& J. Cortés (eds.), Desarrollo de habilidades informativas en Instituciones de Educación Superior, Ciudad Juárez, Chihuahua: Universidad Autónoma de Ciudad Juárez, 9-14.

Damasio, E. (2010), "A visão de pós-graduandos em Ciências Farmacêuticas sobre a capacitação realizada na utilização do Portal de Periódicos da Capes e seus recursos (UEM)-2004", Revista Brasileira de Pós-Graduação, 7 (13), 366-383. Retrieved from http://eprints. rclis.org/15420/

Du, J. T. \& Evans, N. (2011), "Academic library services support for research information seeking”, Australian Academic \& Research Libraries, 42 (2), 103-120.

Earp, V. J. (2008), "Information source preferences of education graduate students", Behavioral \& Social Sciences Librarian, 27 (2), 73-91. DOI:10.1080/01639260802194974

Fleming-May, R. \& Yuro, L. (2009), "From student to scholar: The academic library and social sciences PhD students' transformation", portal: Libraries \& the Academy, 9 (2), 199-221.

Ford, C. \& Gutiérrez, A. M. R. (1999), "El uso de la tecnología de la información entre investigadores mexicanos: un estudio preliminar", Investigación Bibliotecológica, 13 (27), 41-68. Retrieved from http://www.revistas.unam.mx/index.php/ibi/article/view/3916

Francis, H. (2005), "The information-seeking behavior of social faculty at the University of the West Indies, St. Augustine campus", Journal of Academic Librarianship, 31 (1), 67-72.

Garcia, R. M. \& Silva, H. C. (2005), "O comportamento do usuário final na recuperação temática da informação: um estudo com pósgraduandos da UNESP de Marília”, Revista de Ciência da Informação, 6 (3). Retrieved from http://www.dgz.org.br/jun05/Art_02. htm 
Ge, X. (2010), "Information-seeking behavior in the digital age: A multidisciplinary study of academic researchers", College \& Research Libraries, 71, 435-455.

González Harmon, R. \& Limón González, E. G. (2006), "Estudio del perfil, necesidades de información y programa de formación de usuarios: caso biblioteca de la facultad de filosofía y letras de la UACH", in J. Tarango, G. Ascencio \& P. Murguía (eds.), Información sin fronteras: Compartición de experiencias sobre bibliotecas y centros de información, Chihuahua, México: Universidad Autónoma de Chihuahua, Facultad de Filosofía y Letras, pp. 331-344. Retrieved from http://eprints.rclis.org

Huang, C.-Y. \& Chang, S.-S. (2009), "Commonality of web site visiting among countries", Journal of the American Society for Information Science \& Technology, 60 (6), 1168-1177.

Kayongo, J. \& Helm, C. (2010), "Graduate students and the library: A survey of research practices and library use at the University of Notre Dame", Reference E User Services Quarterly, 49 (4), 341-349.

Khosrowjerdi, M. \& Iranshahi, M. (2011), "Prior knowledge and information-seeking behavior of $\mathrm{PhD}$ and MA students", Library $\&$ Information Science Research, 33 (4), 331-335. DOI:10.1016/j.lisr. 2010.04.008

Korobili, S.; Malliari, A. \& Zapounidou, S. (2011), "Factors that influence information-seeking behavior: The case of Greek graduate students", Journal of Academic Librarianship, 37 (2), 155-165.

Lau, J. (2001), "Faculty-librarian collaboration: A Mexican experience", Reference Services Review, 29 (2), 95-105.

Long, C. M. \& Shrikhande, M. M. (2005), "Improving information-seeking behavior among business majors", Research Strategies, 20, 357-369. DOI:10.1016/j.resstr.2006.12.022

Malliari, A.; Korobili, S. \& Zapounidou, S. (2011), "Exploring the information seeking behavior of Greek graduate students: A case study set in the University of Macedonia", International Information E Library Review, 43 (2), 79-91. DOI:10.1016/j.iilr.2011.04.006

Marcum, D. B. \& George, G. (2003), "Who uses what? Report on a national survey of information users in colleges and universities", D-Lib Magazine, 9 (10). DOI: 10.1045/october2003-george

Mazurkiewicz, O. \& Potts, C H. (2007), "Researching Latin America: A survey of how the new generation is doing its research", Latin American Research Review, 42 (3), 161-182. Retrieved from http:// www.jstor.org/stable/4499393

McNeil, R.A. \& Valk, B.G. (eds.) (1990), Latin American studies: A basic guide to sources ( $2^{\text {nd }}$ ed.), Metuchen, NJ: Scarecrow Press.

Menou, M. J. (2010), "Information behaviour of the "Google generation" as a factor in sustainability for Mexican cities", Aslib Proceedings, 62 (2), 165-174. DOI:10.1108/00012531011034973 
Monroe-Gulick, A. \& Petr, J. (2012), "Incoming graduate students in the social sciences: How much do they really know about library research?", Portal: Libraries and the Academy, 12 (3), 315-335.

Mounce, M. (2010), "Working together: academic librarians and faculty collaborating to improve students' information literacy skills: A literature review 2000-2009”, Reference Librarian, 51 (4), 300320.

Perrett, V. (2004), "Graduate information literacy skills: the 2003 ANU skills audit", Australian Library Journal, 53 (2), 161-171.

Pinheiro, M. I. da S.; Carvalho, A. de L.; Silva, E. R. P. da \& Silva, S. M. da (2008), "Informação virtual no processo da formação profissional”, Revista Interamericana de Bibliotecología, 31 (1), 111133.

Poynder, Richard (2013), "Dominique Babini on the state of open access: Where are we, what still needs to be done?", July 25 [Web log post]. Retrieved from http://poynder.blogspot.co.uk/2013/07 /dominique-babini-on-state-of-open.html

Quiroa Herrera, L., Quijano Solis, Á., Vega Díaz, G. \& Palacios Salinas, C. (2011), "Impacto de la biblioteca académica mexicana en la sociedad del conocimiento", Ibersid: Revista de Sistemas de Información y Documentación, 5, 51-60. Retrieved from http://www. ibersid.eu/ojs/index.php/ibersid/index

Ramos, E. (2004), Apoyo bibliotecario al proceso de enseñanza - aprendizaje a alumnos de postítulo y magister de nutrición de la facultad de medicina, Ciudad Juárez, Chihuahua: Universidad Autónoma de Ciudad Juárez.

Rempel, H. G. (2010), “A longitudinal assessment of graduate student research behavior and the impact of attending a library literature review workshop", College \& Research Libraries, 71 (6), 532-547.

Researchers of tomorrow: The research behaviour of Generation $Y$ doctoral students (2012). Retrieved from http://www.jisc.ac.uk/media/documents/publications/reports/2012/researchers-of-tomorrow.pdf

Rodríguez Borrell, C. M. (2006), "Las bibliotecas universitarias en el contexto académico", in J. Tarango, G. Ascencio \& P. Murguía (eds.), Información sin fronteras: Compartición de experiencias sobre bibliotecas y centros de información, Chihuahua, México: Universidad Autónoma de Chihuahua, Facultad de Filosofía y Letras, 261-271. Retrieved from http://eprints.rclis.org

Romanos de Tiratel, S. (2000), "Accessing information use by humanists and social scientists: A study at the Universidad de Buenos Aires, Argentina", The Journal of Academic Librarianship, 26 (5), 346-354.

Russell, J. M.; Ainsworth, S. \& Diaz-Aguilar, J. (2012), "Web visibility or wasted opportunity? Case studies from Mexican research institutes", Aslib Proceedings: New Information Perspectives, 64 (1), 67-82. DOI:10.1108/00012531211196710 
Santos, F. B. dos (2008), Comportamento de busca da informação ambiental por pesquisadores da área de meio ambiente (Doctoral dissertation, Universidade Estadual Paulista, Marília, Brazil). Retrieved from http://www.athena.biblioteca.unesp.br/exlibris/bd/ bma/33004110043P4/2008/santos_fb_me_mar.pdf

The 2012 State of America's Libraries: A Report from the American Library Association [Special Issue]. Retrieved from http://www.ala. org

Tinker-Salas, M. (2009), "North and south inequalities in access to scholarship persist", LASA Forum, 40 (4), 6-7.

Uribe, A. (2012), "Alfabetización informacional en las bibliotecas universitarias venezolanas”, Enl@ce Revista Venezolana de Información, Tecnología y Conocimiento, 9 (1), 73-87. Retrieved from http://www.redalyc.org

Vargas, B. C. (2008), "An approach to the information services and collections of Mexican digital libraries", Revista Interamericana de Bibliotecología, 31 (2), 119-139.

Vezzosi, M. (2009), "Doctoral students' information behaviour: an exploratory, study at the University of Parma (Italy)", New Library World, 110 (1/2), 66-80. DOI:10.1108/03074800910928595

Wilson, T. D. (2010), "Fifty years of information behavior research", Bulletin of the American Society for Information Science and Technology, 36 (3), 27-34. DOI:10.1002/bult.2010.1720360308 
APPENDIX:

Group One Survey Results

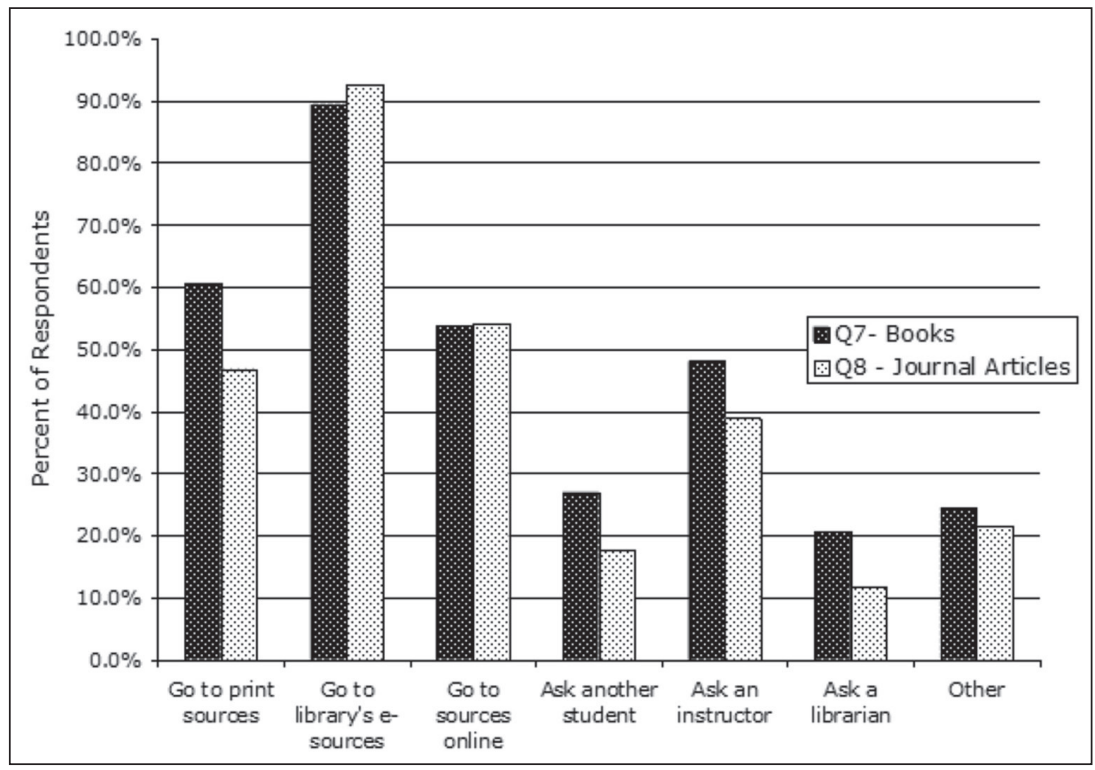

Figure 5. How Group One students find books and journal articles.

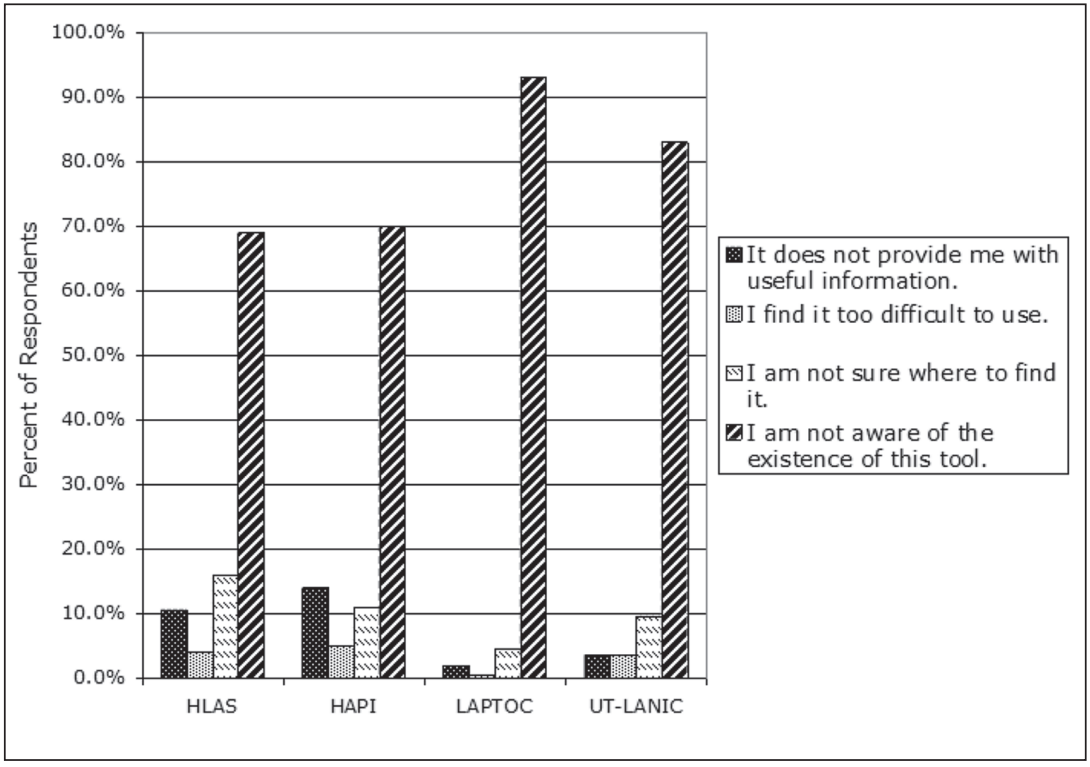

Figure 6. Group One reasons for non-use of tools. 
Table 3. Group One's most useful tools for Latin America-related research in order of number of respondents.

\begin{tabular}{|l|c|l|c|}
\hline JSTOR & 66 & Sociological Abstracts & 2 \\
\hline OCLC WorldCat/FirstSearch & 42 & AA Index & 1 \\
\hline LANIC & 28 & ABI Inform & 1 \\
\hline MLA & 27 & Brasil.gov & 1 \\
\hline HAPI & 26 & Cambridge Abstracts & 1 \\
\hline Libraries' Catalog/Web Site & 25 & CEPAL & 1 \\
\hline Bibliographies/Research Guides & 23 & CIRMA Guatemala & 1 \\
\hline Google/Internet & 17 & Current Contents & 1 \\
\hline HLAS & 14 & Dissertation Abstracts & 1 \\
\hline EBSCOhost & 12 & eHRAF & 1 \\
\hline Academic Search Elite/Premier & 10 & EndNote & 1 \\
\hline LexisNexis & 10 & Ethnic NewsWatch & 1 \\
\hline Web of Science/Knowledge (SSCI) & 9 & Famsi.org & 1 \\
\hline Colleagues and Professors & 8 & Field Contacts & 1 \\
\hline Latin American Research Review & 8 & Gender Watch & 1 \\
\hline Project Muse & 8 & HOBCO & 1 \\
\hline ERIC & 7 & Humanities Abstracts & 1 \\
\hline ProQuest & 7 & Latin American Abstracts & 1 \\
\hline Melvyl (University of California) & 6 & Latin American Studies & 1 \\
\hline Anthropological Literature/Index & 5 & Latindex & 1 \\
\hline Electronic Journals & 5 & Library of Congress Web Site & 1 \\
\hline ECO & 4 & Medline & 1 \\
\hline InfoTrac & 4 & New Left Review & 1 \\
\hline Archives in Latin America & 3 & OVID & 1 \\
\hline Online Newspapers & 3 & Popline & 1 \\
\hline Political Database of the Americas & 3 & PsycINF0 & 1 \\
\hline ArticleFirst & 2 & PUC Rio Web Site & 1 \\
\hline ATLA & 2 & RLIN & 1 \\
\hline EconLit & 2 & SciELO & 1 \\
\hline Expanded Academic Index & 2 & U.S. Census & 1 \\
\hline Ingenta & 2 & WilsonWeb & 1 \\
\hline PAIS International & 2 & World Bank Publications & 1 \\
\hline Publishers' Web Sites & 2 & Worldwide Political Science & 1 \\
\hline & & Abstracts & \\
\hline
\end{tabular}


RESEARCHING LATIN AMERICA, PART TWO:..

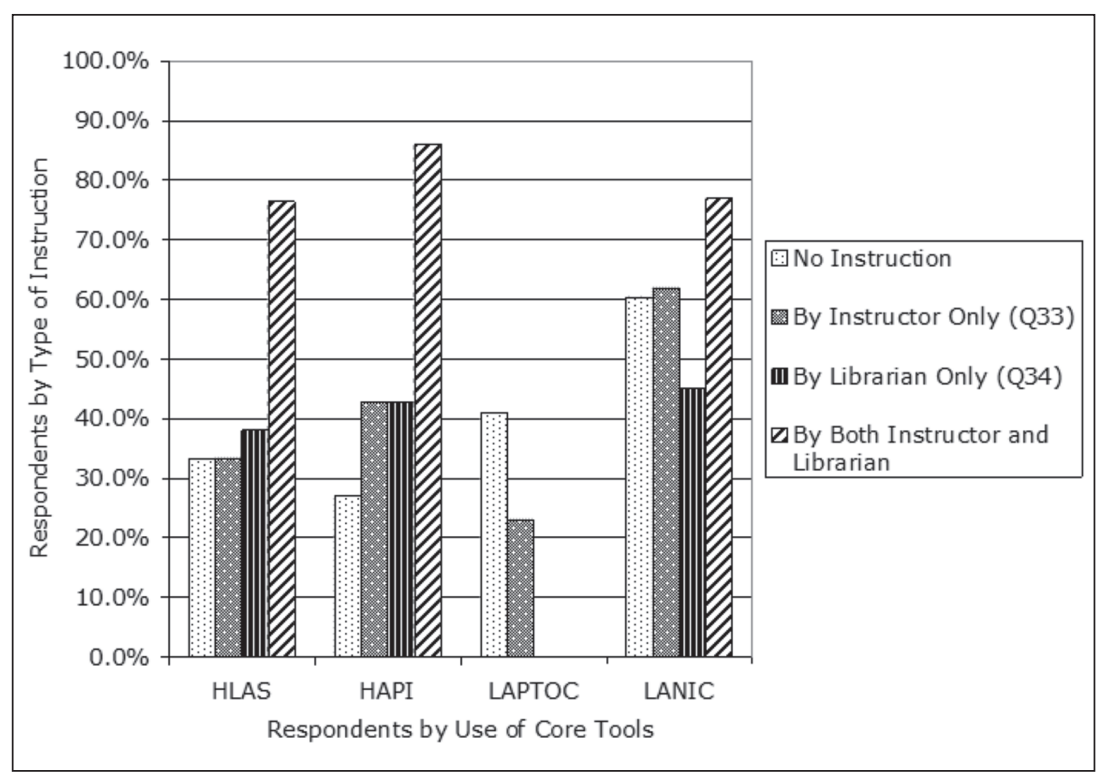

Figure 7. Group One's use of the tools and bibliographic instruction.

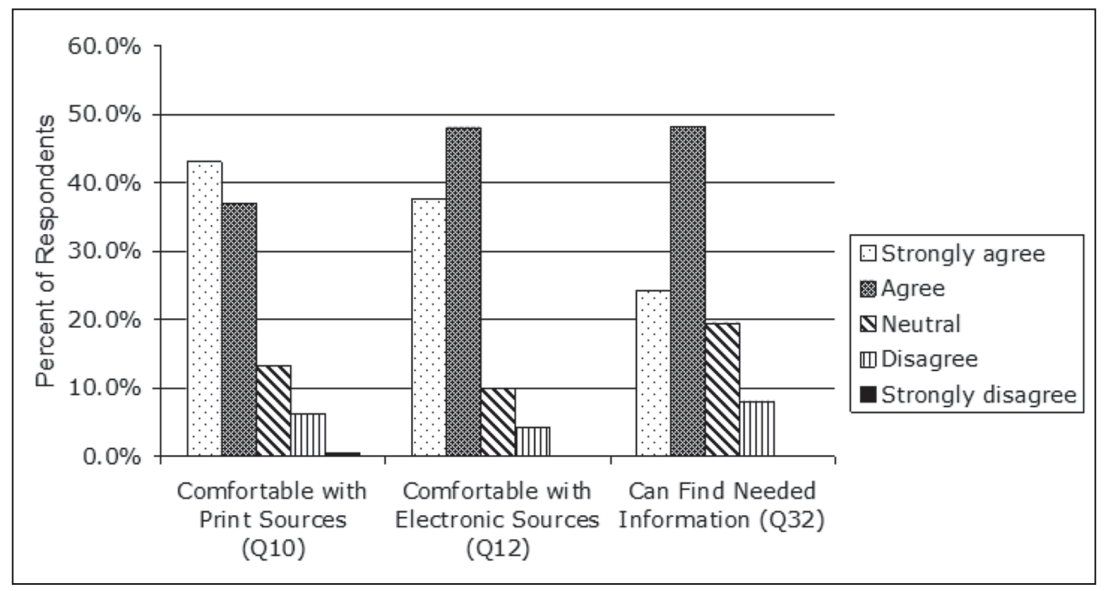

Figure 8. Group One's self-assessed comfort levels. 


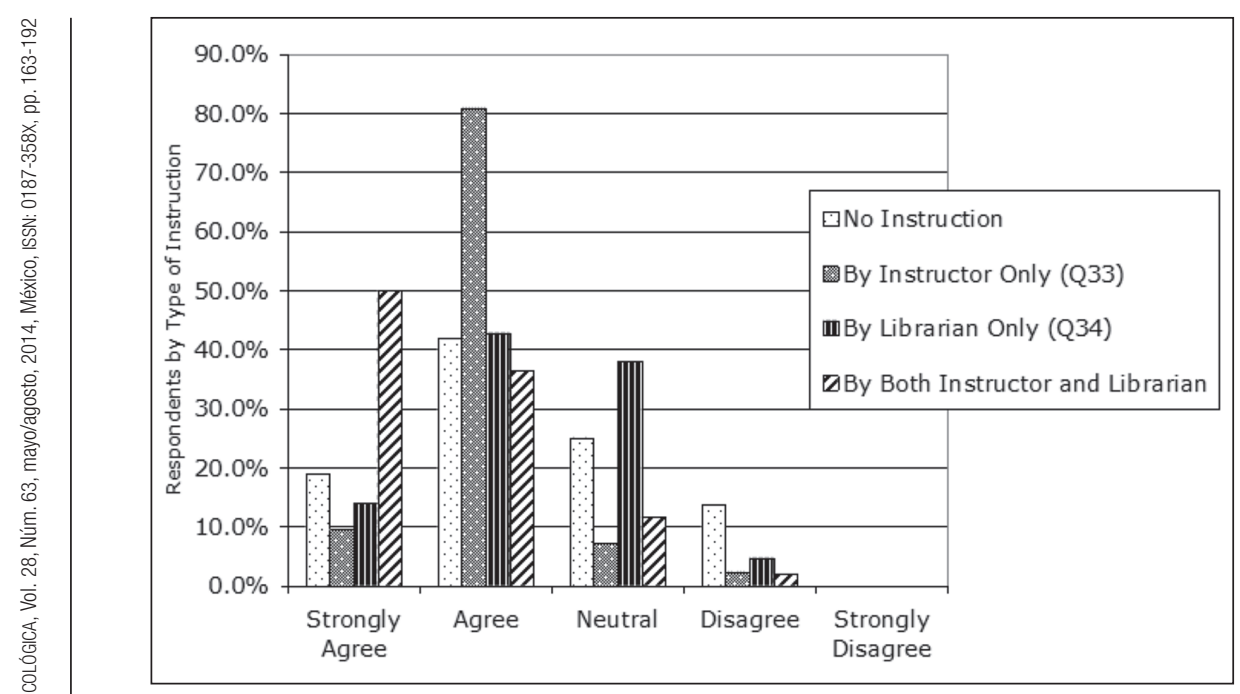

Figure 9. Group One's agreement with "I can find the information I need on Latin America-related topics" and bibliographic instruction.

$\infty$ 